\title{
Commentary on Mitochondrial Stereology in Transmission Electron Microscopy
}

\author{
Comentario sobre Estereología Mitocondrial en Microscopía Electrónica de Transmisión
}

Pedro Henrique Reis-Barbosa ${ }^{1,3}$; Jorge José de Carvalho ${ }^{3}$; Mariano del Sol ${ }^{2} \&$ Carlos Alberto Mandarim-de-Lacerda $^{1}$

REIS-BARBOSA, P. H.; DE CARVALHO, J. J.; DEL SOL, M. \& MANDARIM-DE-LACERDA, C. A. Commentary on mitochondrial stereology in transmission electron microscopy. Int. J. Morphol., 38(1):26-29, 2020.

SUMMARY: Mitochondria (m) are responsible for the energy availability of cells, and their analysis is indicated for example, in studies related to metabolism and oxidative stress. The direct measurement of mitochondria (morphometry) is biased because of the section obliquity and position relative to the mitochondria length (non-equatorial cut). Therefore, stereology is an appropriate technique to evaluate mitochondria. However, before beginning the study, it is necessary to consider the premises to obtain random and uniform samples to be analyzed stereology. Mitochondria must have the chance to appear in all the possibilities of cut and orientation in the micrographs. The number of micrographs to be analyzed will depend on the distribution and occupation of mitochondria in the cell. After this is resolved, a proposal is the estimation of the following stereological data: volume density (Vv), surface density (Sv), and mean cross-sectional area (A). Overlapping a known test area at each micrograph, the density by area of mitochondria is estimated $\left(\mathrm{N}_{\mathrm{AT}}\right)$. $\mathrm{Vv}$ [m] can easily be estimated by point-counting $\left(\mathrm{Vv}=\mathrm{Pp} / \mathrm{P}_{\mathrm{T}}\right.$; $\mathrm{Pp}$ are the points hitting the structure, $\mathrm{P}_{\mathrm{T}}$ are the number of points of the test system). Sv is estimated overlaying a test-line $\left(\mathrm{L}_{\mathrm{T}}\right)$ on the micrographs and counting the intersections of the lines (I) with the outer membrane (om), inner membrane (im), and crests (c), thus, $\mathrm{Sv}[\mathrm{om}], \mathrm{Sv}[\mathrm{im}], \mathrm{Sv}[\mathrm{c}]\left(\mathrm{Sv}=2 \mathrm{I} / \mathrm{L}_{\mathrm{T}}\right) . \mathrm{A}[\mathrm{m}]$ is obtained as the ratio: $\mathrm{A}=\mathrm{Vv} / 2 \mathrm{~N}_{\mathrm{AT}}$.

KEY WORDS: Mitochondria; Morphometry; Stereology; Microscopy; Cell biology.

\section{INTRODUCTION}

For over four decades, it has been speculated that mitochondria originated from a symbiosis between the eukaryotic cell and bacteria (Reijnders, 1975). Moreover, research in the last decade has highlighted that since its integration in eukaryote cells, this organelle of bacterial origin has not only been tolerated by immunity but has also been placed as a central regulator of cell defense, which reinforces the interest of mitochondrial research (Meyer $e t$ al., 2018).

The mitochondria have multiple essential features and have attended in contemporary literature (Picard et al., 2016; van der Bliek et al., 2017) because of its performance in generation of reactive oxidation species (Schwerzmann et al., 1989; Ray et al., 2014), apoptosis regulation (Yee et al., 2014), activation of endoplasmic reticulum stress response (Kim et al., 2016), and others. For example, the content of mitochondria differs in various species ranging between 22.0-37.0 \% with a close correlation between the mitochondrial volume density, heart rate and the rate of basal oxygen consumption in any group of animals (Barth et al., 1992).

Mitochondrial disorders represent a heterogeneous group of multisystem diseases with extreme variability in clinical phenotype. Ultrastructural analysis revealed a heterogeneous mixture of mainly abnormal, partially swelling mitochondria with unusual and sparse cristae, which highlights the importance of morphological analysis in diagnostics of mitochondrial disorders (Brantová et al., 2006). Therefore, the shape and size of mitochondria may be varied in different tissues and when subjected to metabolic, physiological, and pathological changes. For example, when the inner mitochondrial membrane had lost

\footnotetext{
${ }^{1}$ Laboratory of Morphometry, Metabolism, and Cardiovascular Diseases. Biomedical Centre, Institute of Biology, The University of the State of Rio de Janeiro, Rio de Janeiro, Brazil.

${ }^{2}$ Doctoral Program in Morphological Sciences, Universidad de La Frontera (UFRO), Temuco, Chile.

${ }^{3}$ Laboratory of Ultrastructure and Tissue Biology. Biomedical Centre, Institute of Biology, The University of the State of Rio de Janeiro, Rio de Janeiro, Brazil.
} 
its selective permeability originates a swelling in the mitochondrial matrix, which distends the outer membrane until it ruptures (Sesso et al., 2012), which is relevant information associated to mitochondrial size and shape.

However, the way mitochondria appear in electron micrographs is varied because mitochondria can be sectioned in different planes, which gives different obliquities in mitochondrial profiles (Fig. 1). This possibility of altering the profile related to the section plane in which the mitochondria are sectioned makes it challenging to diagnose changes in size and shape in the mitochondria. Because of the irregular shape of the mitochondria, stereology may give objective quantitative data and allows easy comparisons between mitochondria of different experimental and pathological situations (Mandarim-de-Lacerda, 2011). Therefore, measuring organelle boundaries (morphometry) to determine diameters, lengths, shapes, is often misleading (distorted) and does not help in mitochondria assessment.

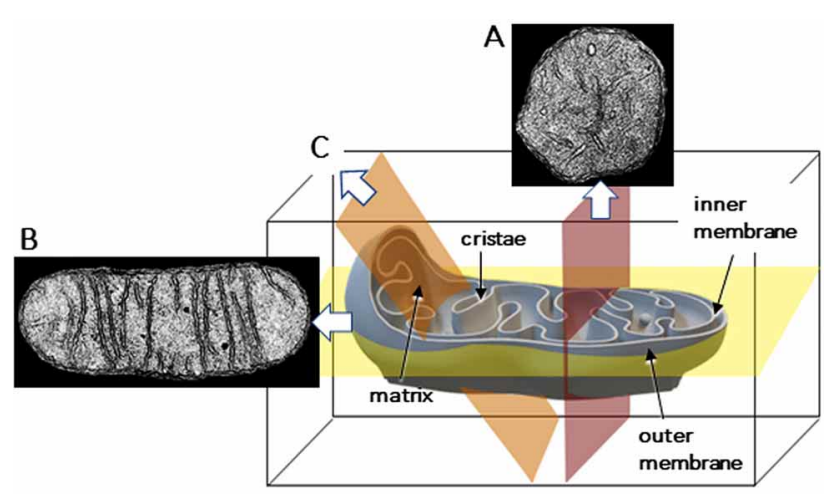

Fig. 1. Mitochondria may appear sectioned in various orientations: (A) round shape when sectioned transversely, (B) elongated shape when sectioned longitudinally, and (C) all intermediate possibilities.

In this text we intend to indicate procedures and techniques that can help the morphologist and the pathologist and study the quantitative variations of mitochondria in any tissue, contributing to a better understanding of mitochondrial alterations of various standard and pathological causes.

\section{Technical preparation of samples (transmission} electron microscopy). It is crucial to prepare the material accurately for observation by transmission electron microscopy, which beginning with the fixation, resin embedding, ultramicrotomy, and contrast with a previously established and tested protocol. Also, the images to be analyzed must be at the same magnification and be obtained at random. The electron microscope should be calibrated and free of magnetic lens aberrations (which can deform mitochondrial images). Typically, several resin blocks should be got for each individual, each block having a random and varied orientation of the tissue under analysis, which will allow images of mitochondria to be attained at all cutting possibilities (that is essential for the execution of stereology).

2. Estimating mitochondrial stereology. Here we propose to estimate some parameters that we find useful for studying quantitative changes in mitochondria: volume density, numerical density per area, cross-sectional area, and surface density (for cristae and inner and outer membranes). Before proceeding, it is essential for the reader to be familiar with the stereology (jargon and principles) that are easily found in review articles (Gundersen et al., 1988; Cruz-Orive \& Weibel, 1990; Mandarim-de-Lacerda, 2003; Mandarim-deLacerda \& Del-Sol, 2017), and textbooks (Weibel, 1979; Elias et al., 1983; Russ \& Dehoff, 2000; Howard \& Reed, 2005; Mouton, 2011).

For data acquisition and execution of stereological formulas, it is necessary to overlay a test system that contains test area, points, and test lines. With transmission electron microscope images in JPEG format (Joint Photographic Experts Group, a process of digital image compression) you can use the test systems generated by the Web-based Stepanizer to superimpose the images (www.stepanizer.com) (Tschanz et al., 2011).

Figure 2 illustrates an image of tissue (liver) containing mitochondria with a superimposed test system and will be mentioned in the following descriptions.

a) Volume density of mitochondria in a tissue ( Vv [mit, tissue]). The simplest way to make this estimate is by counting points. In Figure 2, test points are indicated by incomplete circles ( $\mathrm{Pp}$ ) (in this case, 25 points). Only 10 points focus on mitochondria, and, therefore, we have a density of Vv [mit, tissue] $=10 / 25=0.4$ or $40 \%$.

To know how many images and how many points should be counted for the results to be statistically significant, we suggest consulting a nomogram established for this purpose, as, for example, in previous publications (Weibel; Aherne \& Dunnill, 1982; Mandarim-de-Lacerda, 2011; Mandarim-de-Lacerda \& del-Sol).

\section{b) Numerical density per area of mitochondria in a tissue} $\left(\mathbf{N}_{\mathrm{A}}\right.$ [mit, tissue]). Mitochondria contained in a test area should be counted as long as they are not hit by the "forbidden lines" (exclusion lines) (this is well demonstrated in a Gundersen historical publication) (Gundersen, 1977). 
In Figure 2, the exclusion lines are red and section the two lower mitochondria in the image and those on the left (indicated by $\mathrm{x}$ ). Therefore, in this image, only the mitochondria indicated by numbers 1 and 2 should be considered. If we know the value of the test area (this is determined when we calibrate the system in Stepanizer), $\mathrm{N}_{\mathrm{A}}$ [mit, tissue] is easily calculated.

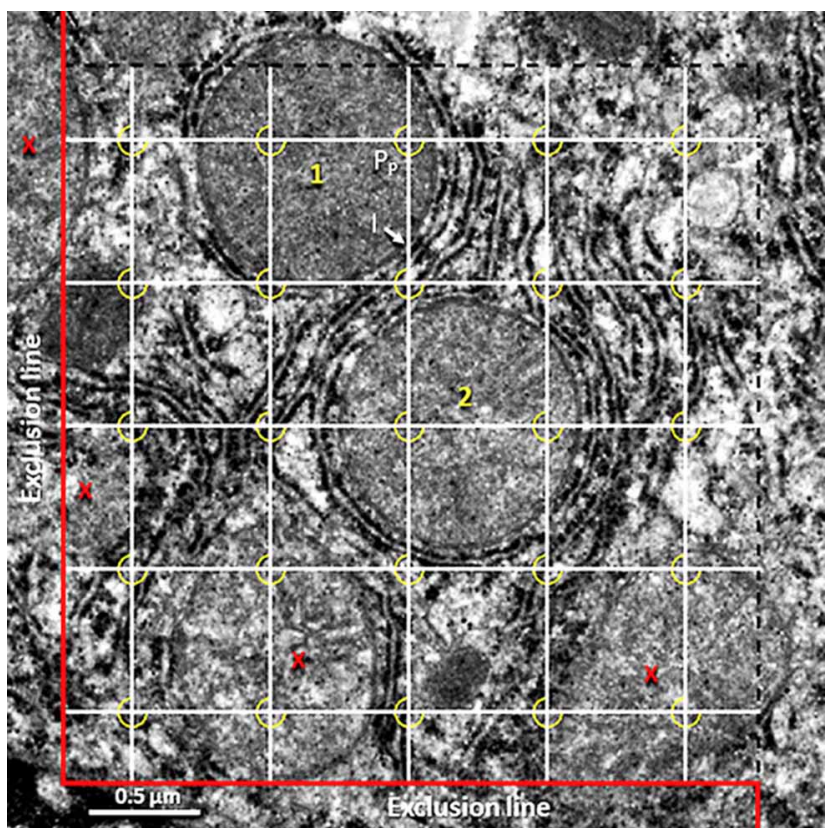

Fig. 2. This figure illustrates an electron micrograph of mitochondria having superimposed a test system for stereological data acquisition. Points ( $\mathrm{Pp}$ ) and intersections (I) of the test line with mitochondria (or their structures) can be counted. The number of mitochondria in the test area can also be computed (\#1 and \#2) if the exclusion lines do not cut them (in this case, mitochondria marked with $\mathrm{X}$ are not totaled).

c) Mitochondrial cross-sectional area (A [mit, tissue]). A [mit, tissue] is defined by the following formula:

$$
A[\text { mit }, \text { tissue }]=\frac{V v[\text { mit, } \text { tissue }]}{2 \times N_{A}[\text { mit }, \text { tissue }]}
$$

moreover, we already learned how to estimate $\mathrm{Vv}$ [mit, tissue] and $\mathrm{N}_{\mathrm{A}}$ [mit, tissue].

d) Surface density ( $\mathrm{Sv}$ [structure, mit]). $\mathrm{Sv}$ is a stereological concept taught by Buffon (1777) in his game of needles [the history of this concept can be read in a previous publication (Mandarim-de-Lacerda, 2003)]. In practical terms, $\mathrm{Sv}$ is calculated as indicated in the following formula:

$$
S v[\text { structure, } \text { mit }]=\frac{2 I}{L_{T}}
$$

( $\mathrm{I}$ is the number of intersections of the test line -- $\mathrm{L}_{\mathrm{T}}$-- with the mitochondrial structure). Sv can be estimated for the outer membrane (om), the inner membrane (im), or cristae (c). Therefore, it is possible to estimate Sv [om,mit], Sv [im, mit] or Sv [c, mit] independently.

Intersections (I) can happen with vertical or horizontal lines, maximizing the count in the same image. In Figure 2, an intersection is indicated with a vertical line.

\section{CONCLUSION}

Although it is not common to find stereological quantification of mitochondria and their membranes in the studies, we intended here to provide some useful tools for anyone who wants to add this quantification to their work, valuable information when studying tissue changes due to physiological or pathological causes.

REIS-BARBOSA, P. H.; DE CARVALHO, J. J.; DEL SOL, M. \& MANDARIM-DE-LACERDA, C. A. Comentario sobre estereología mitocondrial en microscopía electrónica de transmisión. Int. J. Morphol., 38(1):26-29, 2020.

RESUMEN: Las mitocondrias (m) son responsables de la disponibilidad de energía de las células, y su análisis está indicado, por ejemplo, en estudios relacionados con el metabolismo y el estrés oxidativo. La medición directa de las mitocondrias (morfometría) está sesgada debido a la oblicuidad de la sección y la posición relativa a la longitud de las mitocondrias (corte no ecuatorial). Por lo tanto, la estereología es una técnica apropiada para evaluar las mitocondrias. Sin embargo, antes de comenzar el estudio, es necesario considerar las premisas para obtener muestras aleatorias y uniformes para analizar estereológicamente. Es esencial que las mitocondrias tengan la posibilidad de aparecer en todas las posibilidades de corte y orientación en las micrografías. El número de micrografías que se analizarán dependerá de la distribución y ocupación de las mitocondrias en la célula. Una vez resuelto esto, una propuesta es la estimación de los siguientes datos estereológicos: densidad de volumen $(\mathrm{Vv})$, densidad de superficie ( $\mathrm{Sv}$ ) y área de sección transversal media (A). Superponiendo un área de prueba conocida en cada micrografía, se estima la densidad por área de mitocondrias $\left(\mathrm{N}_{\mathrm{AT}}\right)$. $\mathrm{Vv}[\mathrm{m}]$ se puede estimar fácilmente contando puntos $\left(\mathrm{Vv}=\mathrm{Pp} / \mathrm{P}_{\mathrm{T}}\right.$; Pp son los puntos que llegan a la estructura, $\mathrm{P}_{\mathrm{T}}$ son el número de puntos del sistema de prueba). Sv se estima superponiendo una línea de prueba $\left(\mathrm{L}_{\mathrm{T}}\right)$ en las micrografías y contando las intersecciones de las líneas (I) con la membrana externa (om), la membrana interna (im) y las crestas (c), por lo tanto, $\mathrm{Sv}$ [om], $\mathrm{Sv}$ [im], $\mathrm{Sv}$ [c] $\left(\mathrm{Sv}=2 \mathrm{I} / \mathrm{L}_{\mathrm{T}}\right)$. $\mathrm{A}[\mathrm{m}]$ se obtiene como la relación: $\mathrm{A}=\mathrm{Vv} / 2 \mathrm{~N}_{\mathrm{AT}}$.

PALABRAS CLAVE: Mitocondria; Morfometría; Estereología; Microscopía; Biología celular. 


\section{REFERENCES}

Aherne, W. A. \& Dunnill, M. S. Morphometry. London, Edward Arnold Pub., 1982. pp.205.

Barth, E.; Stammler, G.; Speiser, B. \& Schaper, J. Ultrastructural quantitation of mitochondria and myofilaments in cardiac muscle from 10 different animal species including man. J. Mol. Cell. Cardiol., 24(7):669-81, 1992.

Brantová, O.; Tesarová, M.; Hansíková, H.; Elleder, M.; Zeman, J. \& Sládková, J. Ultrastructural changes of mitochondria in the cultivated skin fibroblasts of patients with point mutations in mitochondrial DNA. Ultrastruct. Pathol., 30(4):239-45, 2006.

Buffon, G.-L. Essai d'Arithmétique Morale. Supplement à l'Historie Naturelle. Paris, Imprimerie Royale, 1777. pp.321.

Cruz-Orive, L. M. \& Weibel, E. R. Recent stereological methods for cell biology: a brief survey. Am. J. Physiol., 258(4 Pt. 1):L148-56, 1990.

Elias, H.; Hyde, D. M. \& Scheaffer, R. L. A Guide to Practical Stereology. Basel, Karger, 1983. pp.305.

Gundersen, H. J. G. Notes on the estimation of the numerical density of arbitrary profiles: the edge effect. J. Microsc., 111(2):219-23, 1977.

Gundersen, H. J.; Bendtsen, T. F.; Korbo, L.; Marcussen, N.; Møller, A.; Nielsen, K.; Nyengaard, J. R.; Pakkenberg, B.; Sørensen, F. B.; Vesterby, A.; et al. Some new, simple and efficient stereological methods and their use in pathological research and diagnosis. A. P. M. I. S., 96(5):379-94, 1988.

Howard, C. V. \& Reed, M. G. Unbiased Stereology: Three-Dimensional Measurement in Microscopy. $2^{\text {nd }}$ ed. New York, BIOS Scientific Pub., 2005. pp.277.

Kim, H. E.; Grant, A. R.; Simic, M. S.; Kohnz, R. A.; Nomura, D. K.; Durieux, J.; Riera, C. E.; Sanchez, M.; Kapernick, E.; Wolff, S.; et al. Lipid Biosynthesis Coordinates a Mitochondrial-to-Cytosolic Stress Response. Cell, 166(6):1539-52.e16, 2016.

Mandarim-de-Lacerda, C. A. \& del-Sol, M. Tips for studies with quantitative morphology (morphometry and stereology). Int. J. Morphol., 35(4):1482-94, 2017.

Mandarim-de-Lacerda, C. A. Morphometry and Stereology in Electon Transmission Microscopy. In: De-Souza, W. (Ed.). Electron Microscopy Techniques Applied to the Life Sciences. $3^{\text {rd }}$ ed. Rio de Janeiro, Sociedade Brasileira de Microscopia e Microanálise, 2011. pp.423.

Mandarim-de-Lacerda, C. A. Stereological tools in biomedical research. An. Acad. Bras. Cienc., 75(4):469-86, 2003.

Meyer, A.; Laverny, G.; Bernardi, L.; Charles, A. L.; Alsaleh, G.; Pottecher, J.; Sibilia, J. \& Geny, B. Mitochondria: an organelle of bacterial origin controlling inflammation. Front. Immunol., 9:536, 2018.

Mouton, P. R. Unbiased Stereology: A Concise Guide. Baltimore, John Hopkins University Press, 2011. pp.397.

Picard, M.; Wallace, D. C. \& Burelle, Y. The rise of mitochondria in medicine. Mitochondrion, 30:105-16, 2016.

Ray, A.; Martinez, B. A.; Berkowitz, L. A.; Caldwell, G. A. \& Caldwell, K. A. Mitochondrial dysfunction, oxidative stress, and neurodegeneration elicited by a bacterial metabolite in a C. elegans Parkinson's model. Cell Death Dis., 5:e984, 2014.

Reijnders, L. The origin of mitochondria. J. Mol. Evol., 5(3):167-76, 1975.

Russ, J. C. \& Dehoff, R. T. Practical Stereology. $2^{\text {nd }}$ ed. New York, Kluwer Academic/Plenum Publishers, 2000. pp.381.

Schwerzmann, K.; Hoppeler, H.; Kayar, S. R. \& Weibel, E. R. Oxidative capacity of muscle and mitochondria: correlation of physiological, biochemical, and morphometric characteristics. Proc. Natl. Acad. Sci. U. S. A., 86(5):1583-7, 1989.

Sesso, A.; Belizário, J. E.; Marques, M. M.; Higuchi, M. L.; Schumacher, R. I.; Colquhoun, A.; Ito, E. \& Kawakami, J. Mitochondrial swelling and incipient outer membrane rupture in preapoptotic and apoptotic cells. Anat. Rec. (Hoboken), 295(10):1647-59, 2012.
Tschanz, S. A.; Burri, P. H. \& Weibel, E. R. A simple tool for stereological assessment of digital images: the STEPanizer. J. Microsc., 243(1):4759, 2011.

van der Bliek, A. M.; Sedensky, M. M. \& Morgan, P. G. Cell biology of the mitochondrion. Genetics, 207(3):843-71, 2017.

Weibel, E. R. Stereological Methods. Practical Methods for Biological Morphometry. London, Academic Press, 1979. pp.415.

Yee, C.; Yang, W. \& Hekimi, S. The intrinsic apoptosis pathway mediates the pro-longevity response to mitochondrial ROS in C. elegans. Cell, 157(4):897-909, 2014.

Corresponding author:

Carlos Alberto Mandarim-de-Lacerda

Laboratório de Morfometria,

Metabolismo e Doença Cardiovascular

Centro Biomédico, Instituto de Biologia

Universidade do Estado do Rio de Janeiro

BRAZIL

Email: mandarim@uerj.br

Received: 25-07-2019

Accepted: 19-08-2019 